\title{
Industrial Heritage Landscape of the Lielupe River in Latvia
}

\author{
Daiga Zigmunde, Anna Katlapa, Latvia University of Agriculture
}

\begin{abstract}
The development of production always brings about changes in the landscape, with the emergence of new architectural and technological elements. Due to the changes in technologies and as a result of geopolitical processes, often the existing plants are no longer used or new production facilities built, and thus the post-industrial landscapes emerge. Over time, those once so important production facilities have become the main feature of the identity of a particular site, which is associated not only with visual, but also mental recognisibility of the site through traditions, products manufactured and memories of the local people. Together, this all forms an industrial heritage whose preservation or inclusion in a new modern image, with the emergence of post-industrial landscapes, is becoming an increasingly topical issue. This article deals with the industrial heritage landscape of the Lielupe River in Latvia. Since ancient times the Lielupe River, as one of the largest rivers in Latvia with rich mineral resources, has been an important element in the development of economic activities and production in Latvia. The aim of the research was to identify the causes of the formation of industrial heritage and its impact on the Lielupe cultural landscape. As a result of the research, the main visual and spatial features created by the industrial heritage have been identified in various significant historical periods in Latvia including the present time.
\end{abstract}

Keywords: post-industrial areas, historical analysis of the landscape, impact of industrialization

\section{Introduction}

Industrialization is one of the most significant processes in modern history, which still affects economic, social, geopolitical and landscape changes [4]. Industrial landscapes can be divided according to their physical characteristics - the industrial elements existing in the landscape - into: linear industrial landscapes (hydroelectric power stations and dams, roads and railways), geological industrial landscapes (raw material mining quarries, mines), industrial manufacturing landscapes and urban industrial landscapes (industrial areas on the outskirts of the city) [16]. The landscape is changing, therefore industrial landscapes should be perceived as a process that can also be classified by the degree of industrialization. Mines and quarries are considered to be the primary production landscapes. The discovery of new energy sources leads to the emergence of heavy industry landscapes, which are regarded as the highest point of industrialization. After various stages of industrialization under various circumstances postindustrial and new industrial landscapes can be formed $[11 ; 19 ; 22]$. In the USA and in Western Europe, the issue of post-industrial areas became more topical in the 70's of the 20th century, when, after the so-called "30 golden years", economic stagnation followed leading to the closure of many factories and unemployment [12].

In Eastern Europe, which was still incorporated in the USSR till the end of the 20th century, the issue of post-industrial territories became topical after the collapse of the Soviet Union. The conditions determining the emergence of postindustrial areas were associated with the transition from a planned and state-controlled economy to a

free market economy. The economic downturn was followed by a high unemployment rate and various social problems related to that [12]. Latvia (alongside with Moldova, Armenia, Romania and Bulgaria) was one of the countries which was most severely affected by the collapse of the Soviet regime [21]. Landscapes of post-industrial territories in Latvia consist of former industrial territories and engineering infrastructure serving them, derelict military territories, surrounding residential areas as well as the buildings which were started in the Soviet period and left unfinished till this very day [6]. The land privatization process initiated after the restoration of independence has been one of the reasons for the fragmentation of property nowadays, which has had an impact on the management and harmonious inclusion of postindustrial areas in the contemporary landscape. After joining the European Union in 2004, foreign capital began to flow into Latvia more rapidly which also contributed to the revitalization of postindustrial areas.

Post-industrial areas have a significant potential of becoming an industrial heritage as an evidence of ever-so-important economic activities and traditions of a particular region or place, as well as a link between the modern world and the past [5]. The concept of industrial heritage originated in the middle of the 20th century in Great Britain during the Great Depression, when many production facilities were pulled down, thus losing the evidence of the former industrial landscape .

The industrial heritage landscapes are very diverse due to their evolving over time. Many of 


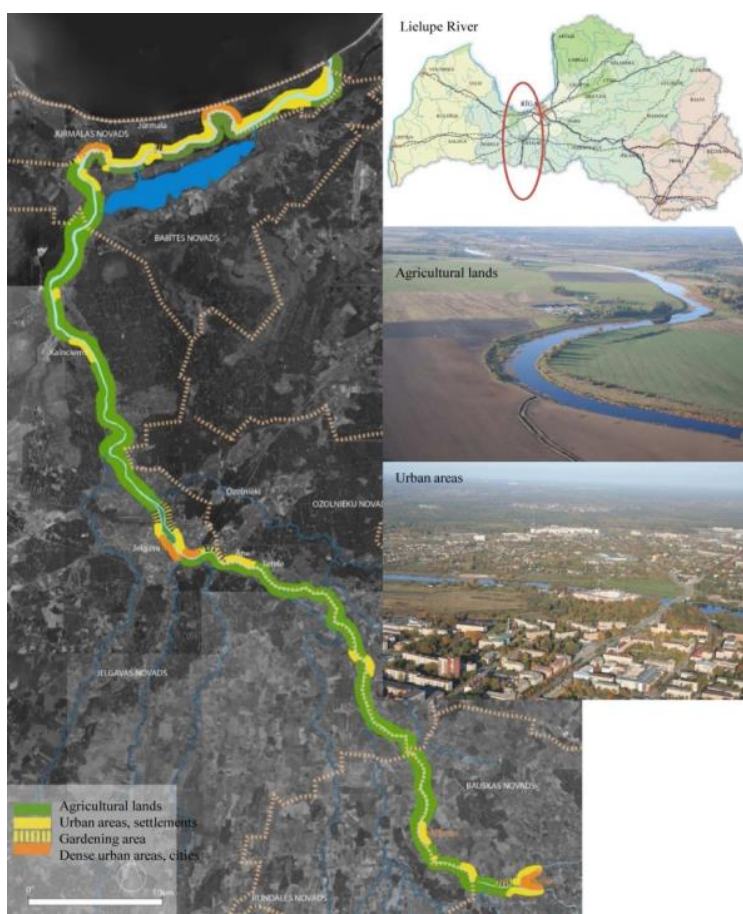

Fig.1. Diverse landscape of the Lielupe River [Source: created by author]

them represent the manufacturing processes, technologies and local economic traditions.

Others are products of global achievements. Some turn into polluted, dangerous, semi-degraded territories due to decline in the local economic activities. Most often historical and currently nonfunctioning manufacturing areas are located close to the historic centers of cities or water courses, in places which presently have a high value of land [2]. Consequently, the inclusion of industrial heritage in the contemporary landscape is a topical subject of urban planning, architecture, landscape architecture and other fields [3].

Visual quality is an important argument for the protection of industrial buildings, but these structures can rarely be considered beautiful. Therefore, the industrial heritage in the cultural landscape is more than just the buildings of an enterprise, it is the combined ability of the facility's history and buildings to narrate a story [8]. If nowadays the industrial heritage of the 19th century and early 20th century finds new applications as tourism objects, residential complexes, etc., then the industrialization of the Soviet period in society is perceived as a transformation of the rural landscape and the disappearance of its traditional form and identity [12].

Nowadays the industrial heritage territories in Latvia have a dual destiny. Due to the lack of management, they naturally collapse and in the long run vegetation takes over the territory, leaving behind ruins. The second development scenario is the transformation of the territories by levelling, preserving them in their existing state, transforming or restoring them.

The Lielupe and Daugava rivers are the largest rivers in Latvia. They have been actively involved in people's economic activities since ancient times, both as transport routes and as a resource. That is the reason why several industrial complexes had been built on the banks of these rivers. The aim of the current research was to identify the causes of the formation of the industrial heritage and its impact on the Lielupe cultural landscape in Latvia.

\section{Material and methods \\ Research object}

The Lielupe River is the largest river in Zemgale region. Its length reaches $119 \mathrm{~km}$ [18]. Consequently, the cultural landscape of the river is diverse since it flows through different types of landscapes (Fig. 1) - agricultural, forest, marshes, protected areas, industrial and urban landscapes.

The geological structure of the Lielupe region has played a decisive role in the development of production in this region. It is mainly characterized by Quaternary period formations, which form the bulk of the mineral deposits of the Lielupe region clay, dolomite, gypsum, peat, sand and gravel, whereas in the northern part - Devonian sedimentary rocks are found - mainly dolomite, limestone, less clay, gypsum and marlstone. One of the most fertile soil types in Latvia - sod carbonate soils and brown soils - are also located in the Lielupe area, which contribute to the development of intensive agriculture in the southern part of the Lielupe [18].

According to the administrative division, the Lielupe flows through 6 municipalities: Bauska, Rundāle, Ozolnieki, Jelgava, Babīte and Jurmala municipalities, and two cities are located on the banks of the river: Jelgava and Jurmala. Each municipality provides for the improvement of the ecological quality of the Lielupe waters, but only a few mention the improvement of the access to water. The development plans of the territory of Jelgava, Ozolnieki, Bauska and Jurmala local selfgovernments include the creation and expansion of the recreational zone of the Lielupe River bank by organizing the infrastructure for pedestrians and cyclists by installing recreation areas, wharfs, jetties, foot-bridges and other infrastructure amenities that would restore life by and in the water $[1 ; 14 ; 15]$.

Following the regulations of the Lielupe management adopted in 2011, which address only the Lielupe River section of Jurmala and Babite municipalities, the main goals of the Lielupe economic exploitation are promotion of water transport, preservation and enhancement of recreational areas, achieving the ecological quality of water, preservation and increase of fisheries 
potential, ensuring the existence and diversity of the flora and fauna of the adjoining territories, protection of historical and cultural objects of Lielupe and the adjoining territories, alongside with ensuring the accessibility of these territories to the public [18].

\section{Methods}

In order to identify the causes of the formation of the industrial heritage of the Lielupe River cultural landscape and the impact on landscape, a study of this region was carried out in the period from 2015-2017, carrying out a general analysis of the Lielupe cultural landscape and conducting the analysis of particular industrial heritage sites. The development of industrial objects has been viewed in the context of the most important geopolitical and economic events of Latvia, distinguishing the following historical stages: the period of the Russian Empire (1770-1915) and the period of the German Empire (1915-1918), the period of the first Republic of Latvia (1918-1940), World War II and the Soviet period (1940-1990), the period of the restored Republic of Latvia (from 1990 to present day), including the period of membership in the European Union and NATO (from 2004 - present day). For data acquisition and interpretation of results, comparative and descriptive methods of historical and contemporary maps and photographs have been used, as well as analysis of archive materials and scientific literature, field studies, interviews with historians and some local people.

\section{Results and discussion}

The advantageous location, size and geological structure of the Lielupe has been a prerequisite for economic activities in the region. Investigating the changes in industrial landscape on the banks of the Lielupe, it has been established that industrial heritage can be divided into visible industrial heritage, formed by the elements of industrial character, and the indirect industrial heritage formed by the products manufactured, technologies used and traditions observed, as well as elements of social and emotional character - such as human memories and cognition.

The period of the Russian Empire (1770-1915) and the period of the German Empire (1915-1918)

During this period, initially the Lielupe River itself was an active element of the economic activities. In Kurzeme province there were two large navigable rivers - the Daugava and the Lielupe. Sometimes, due to thin ice, the Lielupe was navigable almost all the year round. Many tributaries of the Lielupe River and other smaller rivers of Kurzeme were used for floating logs to Jelgava and Riga (Fig. 2). In 1859, the most dangerous places in the log floating waterways were improved - too

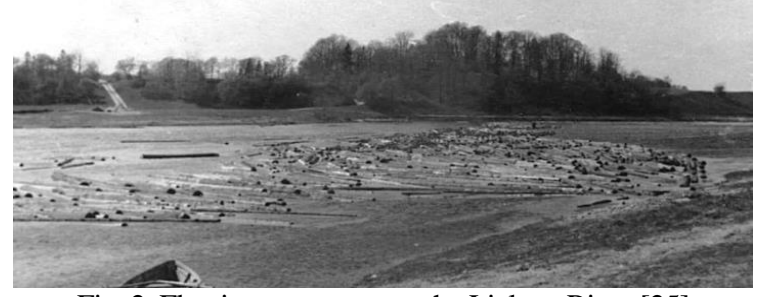

Fig. 2. Floating waterway on the Lielupe River [25] sharp river bends were straightened, rapids were levelled and rocky places were avoided [24]. The natural waterways did not increase the price of manufactured products, water transport had a greater capacity - it could handle larger cargos compared to farmers' carts or sledges. Using river routes, agricultural produce was transported to Riga through Jelgava, whereas the inhabitants of Jelgava were supplied with the necessary goods from Riga.

Before the Agrarian Reform of 1922, manors were the local economic centers, which financed agriculture, brick industry and other economic activities. Along with the construction of the railway lines and roads, road transport won over waterways. At that time, the first railway bridges across the Lielupe were also built - in 1868 a railway line from Riga to Jelgava and in 1877 from Riga to Tukums via Jurmala. In other places, such as Kalnciems, Mezotne, and Jurmala, a ferry was used to transport people across the Lielupe.

In the 1890s, with the development of Riga's industry, active clay mining and kiln building began on the banks of the river Lielupe, which determined the new silhouette of the river with tall chimneys of the kilns [7]. The largest sites with kilns were located in Kalnciems and Ane regions. Due to the geomorphological conditions, the bricks manufactured in Kalnciems were made in a pale yellow tone, while those produced in Ane region had a reddish tint. The bricks were transported by floating them to Riga up the Lielupe River. At the beginning of the 20th century 53 Hoffmann kilns operated in the Lielupe basin, manufacturing 120 million bricks annually [16]. Before World War I the number of Hoffmann kilns increased to 85, manufacturing 230 million bricks a year [9].

The proximity of the river and the deposits of clay and dolomite facilitated not only the creation of production facilities on the right bank of the Lielupe River but also contributed to the development of populated areas which later became cities. Due to the deposits of clay and dolomite, Kalnciems developed into a large building material industry center near the Lielupe waterway, through which at the end of the $19^{\text {th }}$ century the manufactured products were transported to the new construction sites of Riga in barges. Subsequently, the production contributed to the growth of Kalnciems and obtaining the status of the city. 
The proximity of the river and the possibilities of the extraction of dolomite also contributed to the growth of Sloka, when in 1896 one of the oldest and largest paper industry enterprises the Baltic Pulp Mill company in the territory of Latvia was established on the right bank of the river Lielupe alongside with the local dolomite processing cement factory. This company, which had successfully operated for 100 years, including also the period during the first Latvian Republic and in the post-war years until the 1990s, has played a major role in the national economy. Sloka Pulp and Paper Mill together with Ligatne Paper Mill represent the whole industrial sector having a cultural-historical in designing of the factory. The factory supplied Sloka with electricity during its initial operation period.

\section{The period of the first Republic of Latvia} (1918-1940)

After the Agrarian Reform of 1922, the manor lands were confiscated and distributed to landless peasants. During the post-war period, many brick kilns were destroyed and those which were restored faced the shortage of demand and soon stopped working. Agriculture developed rapidly and sugar production was widely spread. In 1926, Jelgava Sugar Factory was founded [7] (Fig. 3). A flax mill was also opened in Jelgava (later it was renamed Flax Factory). Both buildings were destroyed during the war, but after the war they were rebuilt. With the changes in demand and production, the Lielupe Landscape silhouette also changed as the number of the tall chimneys which once dominated the skyline, decreased and larger production sites - building complexes - appeared.

At that time the Lielupe River was still an active element of economic nature. It was used for the transportation of goods and passengers. The increase in the importance of navigation required the construction of harbours and wharfs that were also available to passengers [18]. In 1937, the amount of bricks and lumber transported up and down the river was 0.73 million tons. The number of passangers transported annually was 165,000 [23].

World War II and the Soviet period (1940-1990)

After World War II, the largest city on the banks of the Lielupe - Jelgava lost $90 \%$ of its historical buildings and was actually built anew using a standard type of housing development typical of the Soviet style. Latvia, being incorporated into the Soviet Union, had to provide production in line with its new territorial status. Consequently, industrial production was rapidly developing and during the Soviet era Jelgava became a highly industrial city. Apart from the existing Sugar Factory and Flax Factory, the Leather Factory, Jelgava Dairy and Machine Building Plant were established. With the development of factories, whose task was to provide

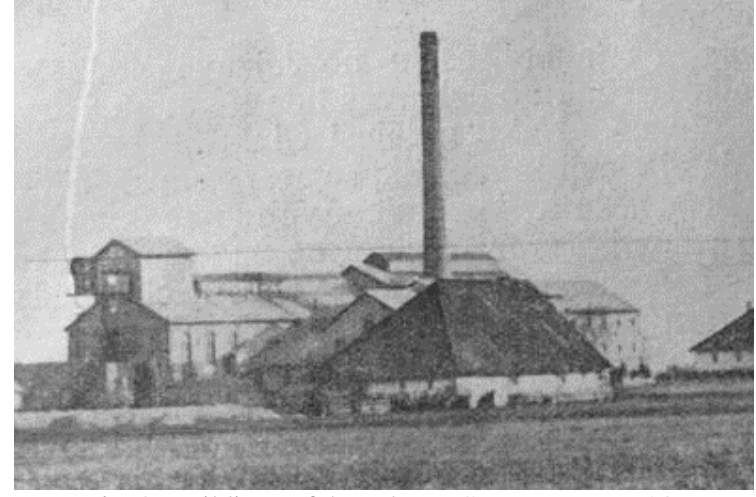

Fig. 3. Buildings of the Jelgava Sugar Factory [23]

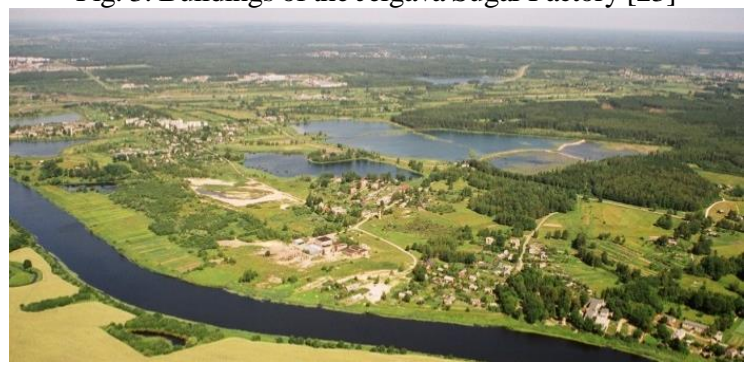

Fig. 4. Clay extraction ponds in Ane and Tetele near the Lielupe River [Source: A. Ziemelniece]

products not only for the inhabitants of Latvia but also for the Soviet Union, Jelgava began to develop along the right bank of the Lielupe. Residential areas for factory workers, who arrived from different places of the Soviet Union, emerged around almost all the large-scale intensive production sites. The transformation of urban landscape of Ane, Tetele, Sloka and Kalnciems is also directly related to the growth of industrial activities. Along the banks of the Lielupe River in the place of the historic Ane Manor and in the vicinity of Tetelmine Manor the production area and clay extraction ponds were formed (Fig. 4). Similarly to Ane, also Kalnciems had turned from a village into a town due to the increase in the production capacity.

Kalnciems Building Materials Complex, established in 1953 and "Spartaks" Plant in Tetele built in 1950, were the largest brick manufacturing plants in Zemgale. They were created by converging earlier existing brickworks [10]. During the Soviet period Sloka experienced a large influx of inhabitants, as a result of which the expansion of the populated areas of the city and the merging with neighbouring populated areas took place.

In 1946, an industrial enterprise - Kalnciems Brick Complex was established as a result of merging of three Kalnciems brick factories "Standarts", "Pūrmali" and "Kaigi". It was an enterprise subordinated to the State Industrial Brick Trust of the Ministry of Building Materials Industry of the Latvian SSR. In the course of its development several additional buildings and workshops were built for its needs. A ferry across the Lielupe River, a complex of apartments and a kindergarten were also built. The main functions of the Kalnciems 
Building Materials Complex were manufacturing of construction bricks, the extraction of splintered lime stone, manufacturing mineral wool and plastic glass [16].

The period of the restored Republic of Latvia (from 1990 till present), including the period of membership in the EU and NATO since 2004

After the collapse of the USSR, the stagnation of the economy in 1991 led to a decline in industrial activity throughout Latvia. There was no longer a need for large-scale factories, thus non-functioning and unmanaged production areas appeared in cities. In search of resources, the government handed over these facilities for privatization, which facilitated the work of self-governments in maintaining the territories, but at the same time loosing control over their historical values. During the period from 1994 to 1997, the largest factories were privatized.

Since 2004, when Latvia joined the European Union and NATO, it became increasingly possible to attract investments for the integration of industrial heritage into the modern landscape. Due to funding from the European Union, under-managed industrial areas were transformed, mainly by completely or partially dismantling old buildings. During the period from 2010 to 2017, many factories along the Lielupe bank were gradually demolished.

Since Jelgava was a typical industrial city, the changes in industrial areas significantly influenced its visual image. The silhouette of the Sugar Factory's production buildings and chimneys disappeared from the bank of the Lielupe river. Instead of those, recreational areas, a promenade and a city beach for residents and guests were made. On the one hand, the city has acquired a quality recreational area, but on the other hand, it has lost its historical identity. The name of the railway station "Sugar Factory" is the only reminder of the former brilliance of the factory. Jelgava Flax Factory also ceased to exist and was partially demolished in 2016 due to the dangers of the construction's design caused by the illegal removal of metal elements during long-term non-management of the building.

Jelgava Building Materials Complex is in a partially functioning condition. From 1991-1995, the State Jelgava Building Materials Complex manufactured fibrolite multilayer insulating boards and it was the only manufacturer of this type of product in the Baltics [13]. Since 2015, two industrial sectors have been represented there - a plastic recycling plant and a facility manufacturing concrete parts, occupying half of the buildings in the territory. An unobstructed barrier of reinforced concrete slabs separates the plant's territory from the other functional zones. A concrete production tower forms the vertical dominant of the territory and is also visible from the railway station "Sugar Factory" and Jelgava bypass road. Since the period of closure of the industrial areas, the local residents have experienced a decline in the quality of life. Prior to this, the factory - and the state - took care of the improvement and maintenance of local areas, but when the status changed from state to private property, people felt dissatisfied and confused as to who should take responsibility. When the factories closed down, many people lost their jobs and moved to other cities, resulting in the decline in the total population and demographic rates.

The production facilities of Ane and Tetele have survived, and they still function but their capacity in manufacturing clay bricks, tiles and other fired building materials, as well as the scope of wholesaling timber, construction materials and plumbing equipment have decreased. The visual image of Kalnciems and the halt in its development are also related to the cessation of production. The operation of Kalnciems Brick Factoty stopped in 1994 and it was divided into 3 companies. Later during the Latvian financial crisis, these production facilities were suspended [16] and gradually from 2011 to 2017 Kalnciems Building Materials Complex was partially demolished (Fig. 5 and 6). It has dramatically changed the landscape of the Lielupe riparian landscape. Clay mining quarries have become naturalized as a recreational place for the local residents. Kalnciems industrial heritage is represented by a view over the former clay ponds and those abandoned production sites which have not yet been demolished - especially chimneys and the water tower.

The Pulp and Paper Mill in Sloka has been partially demolished leaving behind only cultural historical buildings. In 2009, Sloka Pulp and Paper Mill's cultural-historical brick buildings and chimneys were recognized as cultural-historical monuments of which several buildings were preserved: the factory's office building, auxiliary building, the gate, residential building, the first paper mill building, the 19th-20th century chimney, the wood chipping building and the chimney built in 1963. According to the amendments to the territorial plan of Jurmala (functional zoning), the territory is marked as a production type territorry. The chimneys of the Pulp and Paper Mill are already visible from the Jurmala bypass road bridge and the silhouette of the factory is in contrast with the adjacent meadows, forming visual dominance. The most valuable vistas in the territory embrace the Lielupe meadows on the opposite bank. In other parts of the territory there are half-delapidated buildings, ruins of buildings and piles of trash. 


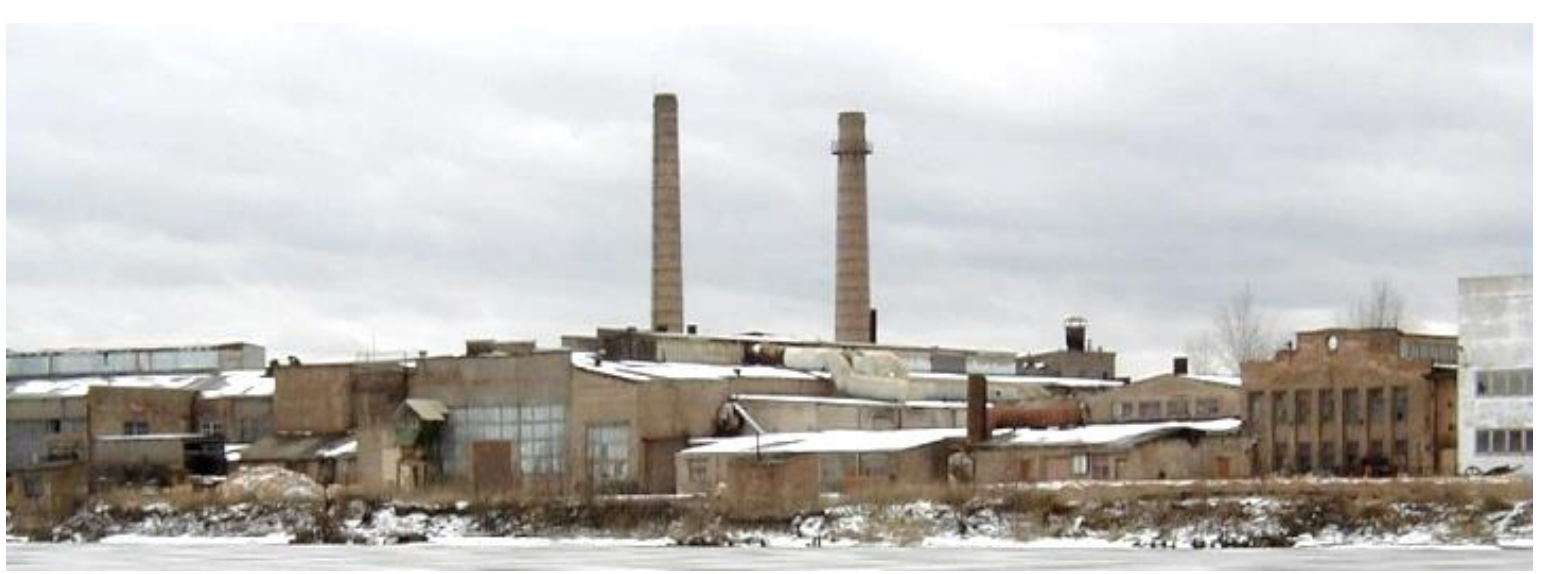

Fig. 5. Kalnciems Building Materials Complex, end of the $20^{\text {th }}$ century [Source: http://mapio.net/pic/p-9562461/]

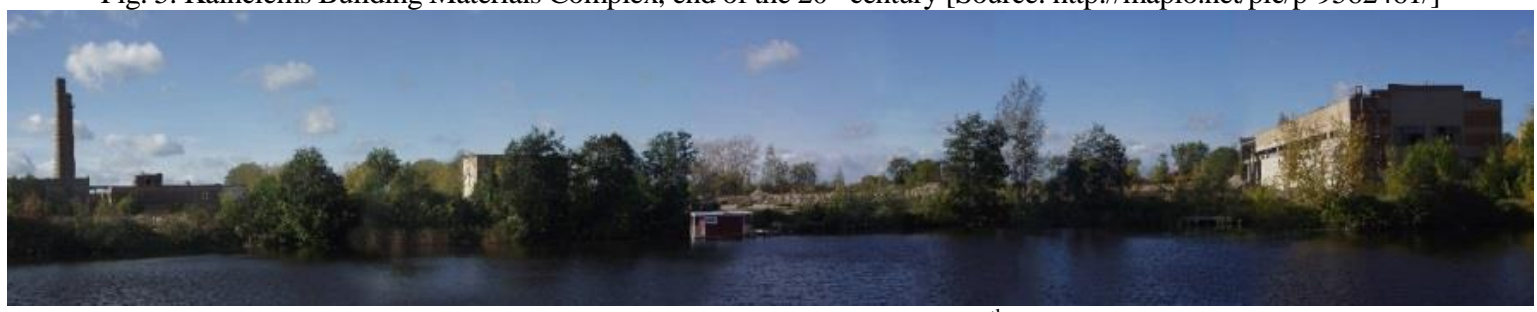

Fig. 6. Kalnciems Building Materials Complex, beginning of the $21^{\text {th }}$ century [Source: A. Katlapa]

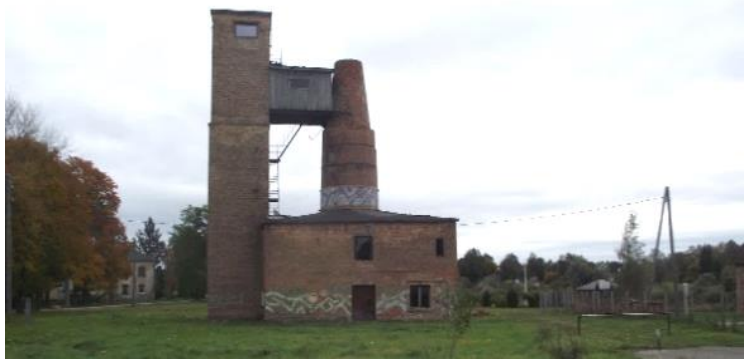

Fig. 7. Brick firing kiln in village Ceplis [Source: A. Katlapa]

The industrial heritage from the 19th century has been preserved in places subject to smaller anthropological load and slower development mainly rural areas. Manor houses, which were significant economic and production centers in the 19 th century, are nowadays being converted into recreational or residential areas. For example, guest houses have been opened in Mezotne and Mazmezotne Manor houses. Bornsminde Manor house was privatized in 2000, and in 2003 it was intended to open a guest house there with 14 rooms, but due to financial problems the plan was not implemented and the estate is in a state of ruins. A similar situation is observed regarding Kaucminde Manor. Its reconstruction requires significant financial investments, but the municipality cannot provide such funds, especially if no proper use of these buildings can be found. In most cases these conditions result in the situation that the fate of cultural monuments depends primarily on the perceptions, desires and opportunities of each owner. The local residents believe that the manor houses are ruinous and dangerous. They also think that not only the owners but also the local people are guilty of ruining the estates by plundering the materials of the manor houses - timber, windows, doors, etc.

Today, the brick buildings of Sloka Pulp and Paper Mill, carcasses of the mills in Sloka and Emburga, as well as the remains of the brick firing kiln in village Ceplis are important witnesses of the 19th century. Taking into account the fact that the brick kilns were usually demolished just after they had been used, it is important to record and document the future development and conservation of the brick kilns. At present, the Kiln is the only historical industrial building that has survived to the present day in Ceplis of Mezotne rural territory, being the only brick kiln that can be viewed. However, it does not have the status of a cultural heritage monument. The kiln building has been converted into a studio and is a children's leisure center (Fig. 7).

The influence of industrial territories on the Lielupe cultural landscape in the context of the most significant historical periods in Latvia is shown in Fig. 8. Gunita Osīte, a researcher at Latvia University of Agriculture and manager of Jelgava City Development and Urban Planning Department, in her study on the possibilities of returning historical production areas to the city's landscape, concluded that much attention should be paid to the architectural and functional rehabilitation of these zones, since they dramatically affect the image and identity of the city, as well as the public's perception, and they are an important part of the urban planning structure [20]. 


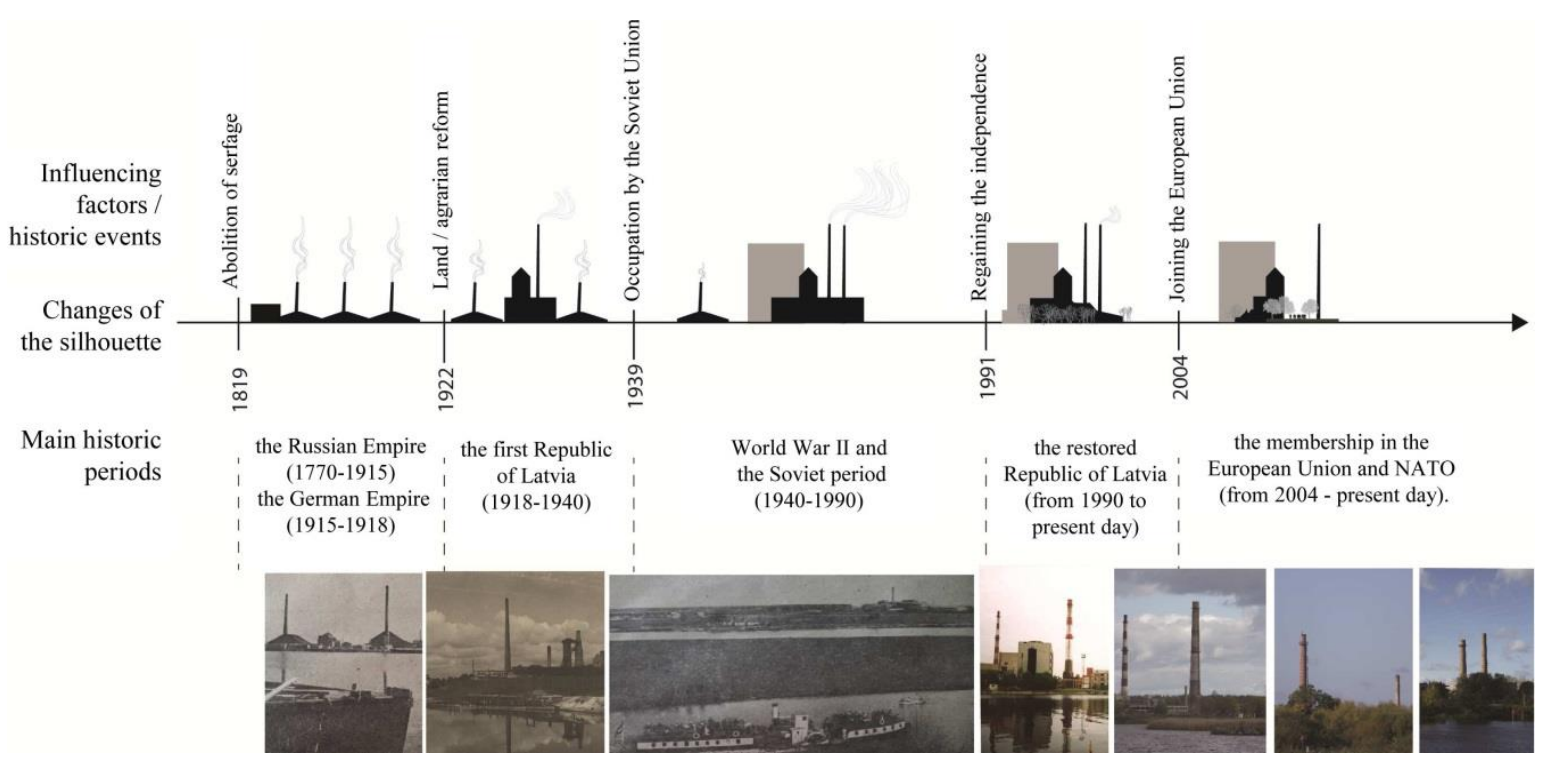

Fig. 8. The influence of industrial territories on the Lielupe cultural landscape in the context of the most significant historical periods in Latvia [Source: created by author]

\section{Conclusions}

The development of industrial heritage in the Lielupe cultural landscape has been promoted by the river itself as an important economic resource and a transport and communication corridor alongside with the geological values of the Lielupe territory clay, dolomite and other mineral deposits. The available resources have influenced the development of specific production facilities whose buildings and technical elements have determined the visual image, structure and silhouette of the Lielupe cultural landscape since the 19th century.

However, apart from the favourable economic environment and available resources, geopolitical processes have played a significant role in the formation or disappearance of the industrial heritage in the Lielupe cultural landscape. Initially, it was the economic activities of the manor houses and the silhouette created by the first chimneys of clay kilns. Later, with changing technologies and production intensity, larger industrial complexes appeared. Then due to the economic downturn and changes, the silhouettes of once so powerful enterprises disappeared or ruins appeared in the landscape, but as soon as investments were attracted, the industrial territories were demolished or revitalized and included in the contemporary landscape.

Occasionally overlayering of historically significant processes is observed bringing about changes in the visual image of landscape, but nevertheless, keeping alive the memories of historical events. For example, the territories of manors, which, under the influence of various land reforms and political decisions, have been fragmented, lost or transformed. Langervalde Manor, for example, had been transformed into Jelgava Building Materials Factory.

Today, most industrial heritage sites have been privatized, and they are beyond the direct influence of municipalities, therefore owners often choose not to take into account the industrial heritage and carry out complete demolition of old buildings. The main task of preserving the industrial heritage is to preserve the narrative of the production process preserving its historical identity. Territories closer to the city center are more likely to become a socially significant object of interest.

\section{References}

1. Bauskas novada teritorijas plānojums 2012.-2023.gadam (Bauska Municipality Territorial Planning for 2012-2023) [online 1.07.2017.]. http://www.bauska.lv/lv/pasvaldiba/publiskie-dokumenti/teritorijas-planojums

2. Bellakova, E. Analysis of Industrial Architectural Heritage - Iron and Steel Plants as a Development Potential. Procedia Engineering, 2016, No. 161, pp.1926-1931.

3. Blagojevic, M.R., Tufegdzic, A. The new technology era requirements and sustainable approach to industrial heritage renewal. Energy and Buildings, 2015, No. 115, pp. 148-153.

4. Chan, E.C. What roles for ruins? Meaning and narrative of industrial ruins in contemporary parks. Journal of Landscape Architecture, 2009, No. 4 (2), pp.20-31.

5. Clark, J. Adaptive Reuse of Industrial heritage: Opportunities \& Challenges. Melbourne: Heritage Council of Victoria, 2013, $20 \mathrm{p}$.

6. Degradēto teritoriju izpēte Rīgas pilsētāa (Research of degraded areas in Riga City) [online 1.07.2017.]. http://www.sus.lv/sites/default/files/media/faili/08_degradetas_teritorijas_riga.pdf

7. Dravnieks, F. Lielupe. Rīga: Valters un Rapa, 1932.

8. Edensor, T. Industrial ruins: spaces, aesthetics, and materiality. New York: Berg Publishers, 2005, 200 p. 
9. Grosvalds, I. Latvijas dzīlu bagātības. Rīga: Zinātne, 1970, 170 lpp.

10. Grosvalds, I., Alksnis, U. Būvkeramikas izstrādājumu ražošana Latvijā (1944-1990). The Production of Building Ceramics in Latvia (1944-1990). The Humanities and Social Science. History of Science and Higher Education: Scientific Journal of Riga Technical University, 2010, No.16, p. 38-41.

11. Hilpert, U. Regionalisation of Globalised Innovation. Locations for advanced industrial development and disparities in participation. London: Routledge, 2003, $272 \mathrm{p}$

12. Industrial heritage around the Baltice Sea. M. Nisser, I. Isacson, A. Lundgren, A. Cinis (eds.) Uppsala:Uppsala universitet, 2012, 264p.

13. Jelgavas būvmateriālu kombināta vēsturiskā liecība (Historical Evidence of the Jelgava Building Materials Complex), Archive Foundation No.575, n.d.

14. Jelgavas novada teritorijas plānojums 2012.-2023.gadam (Jelgava Municipality Territorial Planning for 2012-2023) [online 1.07.2017.]. http://www.jelgavasnovads.lv/lv/pasvaldiba/publiskie-dokumenti/jelgavas-novada-teritorijasplanojums-2011-2023-gadam/

15. Jūrmalas pilsētas teritorijas plānojuma grozijumi 2016.-. gadam. Teritorijas izmantošanas un apbūves noteikumi (Jurmala City Territorial Planning for 2016-. Regulations for the use and building of the territory) [online 1.07.2017.]. https://www.jurmala.lv/docs/j16/x/TIAN.pdf

16. Kalnciema būvmateriālu kombināta vēsturiskā liecība (Historical Evidence of the Kalnciems Building Materials Complex), Archive Foundation No.662, n.d.

17. Lichi, A. Industrial landscape. Lucrari Stiintifice, Seria-B-LV-2011, 2011, p. 694-698.

18. Lielupes baseins (Basin of Lielupe River) [online 1.07.2017.]. http://www.upes.lv/informacija/lielupes-baseins

19. Mah, A. Industrial Ruination, Community and Place: Landscape and Legacies of Urban Decline. Toronto: University of Toronto Press, 2012, 240 p.

20. Osīte, G. Rūpniecisko zonu arhitektoniski ainaviskā rehabilitācija Jelgavā (Landscape rehabilitation of industrial areas in Jelgava City). Master Thesis. Jelgava: Latvijas Lauksaimniecības universitāte, 2004, 90 lpp.

21. Philipov, D. Dorbritz, J. Demographic consequences of economic transition in countries of central and eastern Europe. Population studies, No. 39, 2004, 205 p.

22. Pike, A. De-Industralization. In: International Encyclopedia of Human geography. Amsterdam: Elsevier Science, 2009, pp. 51-59.

23. Tomašūns, A. Mana Jelgava. Jelgava: Zemgales Reǵiona kompetenču attīstības centrs, 2015, 224 lpp.

24. $\bar{U}$ dens celi Kurzemes gubernas laikā (1795-1915) (Waterways during the period of Kurzeme province (1795-1915)). Resource of the Gederts Eliass Museuma [online 1.07.2017.]. http://jvmm.lv/Las\%C4\%ABtava/jelgavas-vesturesannales/udens-celi-kurzemes-gubernas-laika-17951915/

25. Zudusī Latvija. Resource of historic photographies [online 1.07.2017.]. http://www.zudusilatvija.lv/

INFORMATION ABOUT AUTHORS:

Daiga Zigmunde, Dr.arch., Professor in Latvia University of Agriculture, specialized in fields: landscape ecology, human perception of landscape, landscape study. E-mail: daiga.zigmunde@1lu.lv

Anna Katlapa, Mg.arch., landscape architect. Field of research: industrial heritage landscapes. E-mail: anna.katlapa@gmail.com

Kopsavilkums. Lielupe un Daugava ir lielākās Latvijas upes, kuras jau kopš seniem laikiem ir aktīvi tikušas iesaistîtas cilvēku saimnieciskajās aktivitātēs - gan kā transporta ceḷi, gan kā resurss. Tāpēc tieši šo upju krastos ir veidojušies vairāki ražošanas kompleksi. Raksts apskata industriālā mantojumu Lielupes kultūrainavu Latvijā. Lielupe kā viena no lielākajām Latvijas upēm ar bagātīgiem derīgo izrakteṇu resursiem jau no seniem laikiem ir bijusi nozīmīgs elements saimnieciskās darbības un ražošanas attīstībai Latvijā. Pētījuma mērḳis ir identificēt industriālā mantojuma veidošanās cēloṇus un ietekmi uz Lielupes kultūrainavu. Izpētes rezultātā noteiktas galvenās industriālā mantojuma veidotās vizuālās un telpiskās iezīmes dažādos Latvijai nozīmīgos vēsturiskajos periodos un mūsdienās.

Industriālā mantojuma veidošanos Lielupes kultūrainavā ir veicinājusi pati upe kā nozīmīgs saimniecisks resurss un transportěšanas un saziņas koridors, un Lielupes teritorijas ǵeoloǵiskās vērtības - māla, dolomīta un citu derīgo izrakteņu atradnes. Tieši pieejamie resursi ir ietekmējuši specifisku ražotņu veidošanos, kuru ēkas un tehniskie elementi jau kopš 19. gs. ir noteikuši Lielupes kultūrainavas vizuālo tēlu, struktūru un siluetu.

Tomēr bez saimnieciskajai darbībai labvēlīgās vides un pieejamiem resursiem, ǵeopolitiskajiem procesiem ir bijusi būtiska loma industriālā mantojuma izveidē vai izzušanā Lielupes kultūrainavā. Sākotnēji muižu saimnieciskā darbība, pirmo māla cepḷu augsto dūmeṇu veidotais siluets. Vēlāk, mainoties tehnolog̣ijām un ražošanas intensitātei, parādās lielāki industriālie kompleksi. Savukārt ekonomiskās lejupslīdes un pārmaiṇu rezultātā ainavā pazūd kādreiz tik varenie ražotṇu silueti vai parādās drupas, bet ienākot investīcijām - industriālās teritorijas tiek nojauktas vai arī revitalizētas un ieklautas mūsdienu ainavā.

Mūsdienās lielākā daḷa industriālā mantojuma teritorijas ir privatizētas un atrodas ārpus pašvaldību tiešās ietekmes, līdz ar to īpašnieki bieži vien izvēlas neṇemt vērā industriālo mantojumu un veikt pilnīgu vecās apbūves nojaukšanu. Galvenais uzdevums industriālā mantojuma saglabāšanā ir nodrošināt ražošanas procesu stāsta saglabāšanu - savas vēsturiskās identitātes saglabāšana. Teritorijām, kas atrodas tuvāk pilsētas centram ir lielāka iespēja kḷūt par sabiedriski nozīmīgu objektu. 